\title{
Symptomatic pancreatic heterotopia treated by local excision
}

\author{
D J De Friend, F W Saa-Gandi, C S Humphrey, D N Foster
}

\begin{abstract}
Non-ulcer dyspepsia is a continuing problem and in many cases a precise cause is never identified. We present five patients with an allegedly uncommon condition - pancreatic heterotopia. They were managed by local excision of the tumour and after a mean (range) follow up of $42(9-80)$ months all remain free of the original symptoms.
\end{abstract}

\section{Patients and methods}

The details of the five patients are summarised in the Table. It can be seen from this, that their presenting symptoms were both variable and non-specific.

All five patients presented with upper gastrointestinal symptoms; three complaining predominantly of dyspepsia and two with a history suggestive of gastric outlet obstruction, associated in one patient with a succussion splash. Three of the patients also complained of alteration in bowel habit, which in two resolved after operation.

The antral tumour was found on gastroscopy in all five patients. In each case the appearance was of a small, smooth extra mucosal lump, which in two instances had a central punctum. Endoscopic biopsy specimen, however, showed pancreatic heterotopia in only two patients. All five patients had histological evidence of chronic gastritis, which was associated with the presence of Helicobacter pylori in one. Barium meal examination outlined the lesion in two of the four patients in whom it was used. The radiological findings of a small intramural mass with a central barium filled niche (Fig 1) were as described in other reports of this condition.'

The five patients all underwent laparotomy and local excision of the tumour, which in each case was located within $3 \mathrm{~cm}$ of the pylorus (Fig

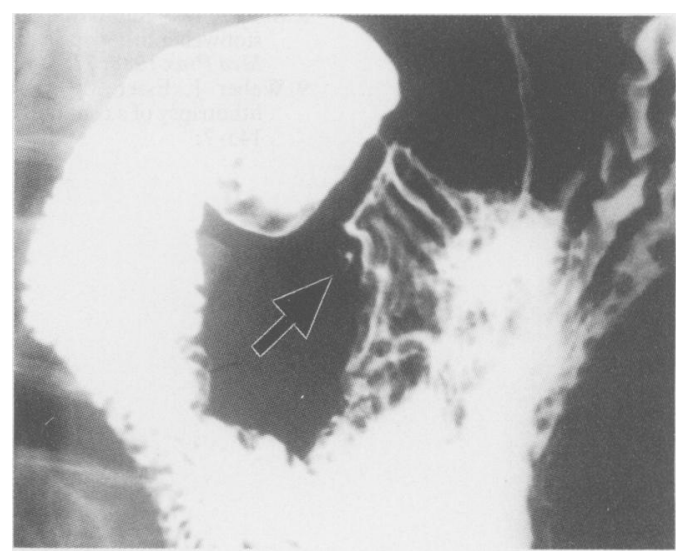

Figure 1: Barium meal from patient four showing a barium filled niche on the greater curve of the antrum (arrow).

2). In one patient the excision was closed as a pyloroplasty, owing to the very close proximity of the lesion to the pylorus. Histology of the excised specimen showed heterotopic pancreas in each case. All the patients made an uneventful postoperative recovery. At a mean (range) follow up of $42(9-80)$ months all the patients remain free of their original symptoms.

\section{Discussion}

Pancreatic heterotopia is defined as the presence, outside its usual location, of pancreatic tissue which lacks anatomical and vascular continuity with the pancreas proper. ${ }^{2}$ It has a reported incidence of $1-14 \%$ on necropsy examination and has been observed in 1 in 500 upper abdominal operations. ${ }^{3}$ Pancreatic heterotopia accounts for up to $7 \%$ of all benign gastric tumours. ${ }^{4}$

In a series of 37 patients reported by Lai and Tompkins, ${ }^{5}$ the heterotopic pancreas was judged

Patient details and investigative findings

\begin{tabular}{|c|c|c|c|c|c|c|}
\hline Patient & Age & Sex & Symptoms & Gastroscopy & Biopsy & Barium meal \\
\hline 1 & 32 & $M$ & $\begin{array}{l}6 \text { week history of belching and } \\
\text { fullness after meals, weight loss } \\
\text { and increased frequency of } \\
\text { bowel habit. Not helped by } \\
\text { antacid plus metoclopramide. }\end{array}$ & 'Hump' in the antrum & $\begin{array}{l}\text { Chronic superficial } \\
\text { gastritis }\end{array}$ & $\begin{array}{l}\text { Extra mucosal lesion in } \\
\text { antrum }\end{array}$ \\
\hline 2 & 71 & $\mathrm{~F}$ & $\begin{array}{l}3 \text { year history of postural } \\
\text { dyspepsia controlled by } \\
\text { cimetidine, } 3 \text { month history of } \\
\text { postprandial colic }\end{array}$ & $\begin{array}{l}\text { Small hiatus hernia. } \\
\text { Sessile lump in antrum. }\end{array}$ & $\begin{array}{l}\text { Chronic gastritis and area } \\
\text { of heterotopic pancreas }\end{array}$ & Not performed \\
\hline 3 & 25 & $F$ & $\begin{array}{l}6 \text { month history of dyspepsia } \\
\text { and changeable bowel habit, } \\
\text { not helped by peppermint oil }\end{array}$ & $\begin{array}{l}\text { Benign looking tumour } \\
\text { in antrum }\end{array}$ & Mild chronic gastritis & Normal \\
\hline 4 & 19 & $M$ & $\begin{array}{l}1 \text { year history of dyspepsia, } \\
\text { vomiting, and diarrhoea } \\
\text { initially helped by cimetidine } \\
\text { and colloidal bismuth, but } \\
\text { relapsed while still on }\end{array}$ & $\begin{array}{l}\text { Gastritis and benign } \\
\text { looking antral tumour } \\
\text { with a central punctum }\end{array}$ & $\begin{array}{l}\text { Chronic gastritis } \\
\text { associated with presence } \\
\text { of Helicobacter pylori }\end{array}$ & $\begin{array}{l}\text { Small regular filling } \\
\text { defect in antrum }\end{array}$ \\
\hline 5 & 49 & $\mathbf{F}$ & $\begin{array}{l}6 \text { month history of } \\
\text { dyspepsia, not helped by } \\
\text { antacid or cimetidine }\end{array}$ & $\begin{array}{l}\text { Mild gastritis and } \\
\text { benign looking antral } \\
\text { tumour }\end{array}$ & $\begin{array}{l}\text { Chronic gastritis and } \\
\text { heterotopic pancreas }\end{array}$ & Normal \\
\hline
\end{tabular}




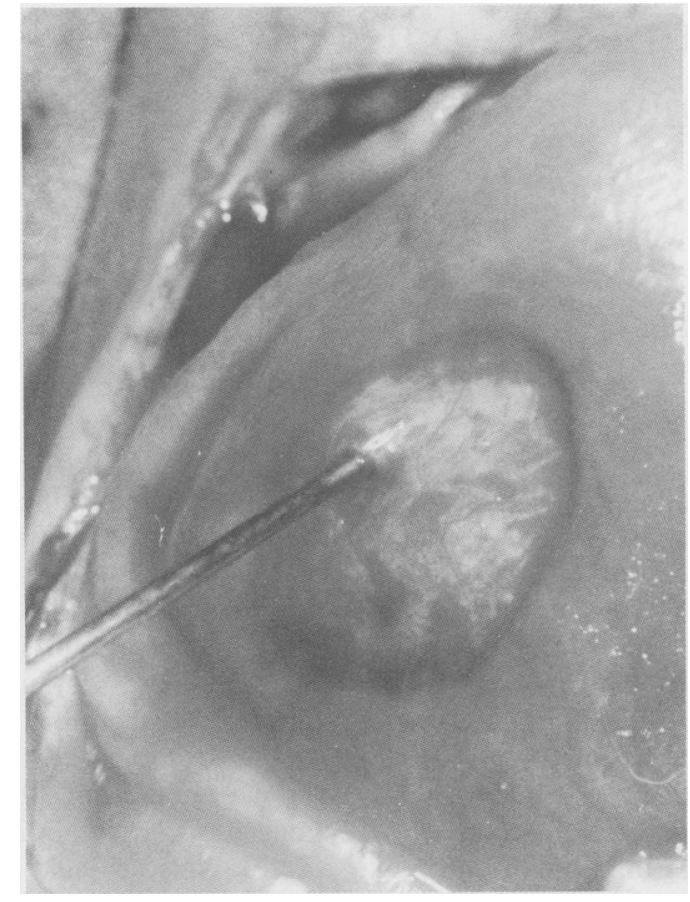

Figure 2: Operative photograph from patient five showing heterotopic pancreatic tissue in gastric antrum with punctum cannulated by probe.

to be responsible for symptoms in nine patients $(24 \cdot 7 \%)$. In these symptomatic patients, the lesion was located in the stomach or duodenum, with the majority occupying a submucosal position in the gastric antrum, as in the five patients reported here.

The role of pancreatic heterotopia in producing symptoms is not clear - overlying gastritis, pylorospasm, and gastric outlet obstruction by larger tumours have all been suggested as possible mechanisms. The symptoms may not be specific for pancreatic heterotopia, however, as other benign prepyloric tumours can present in a similar manner. ${ }^{6}$

Lower gastrointestinal symptoms have not been a feature in previous reports of pancreatic heterotopia. The three patients in this study who complained of alteration in bowel habit were all in the younger age group and coincidental causes, particularly the irritable bowel syndrome, cannot be ruled out. It is of note, however, that the altered bowel habit resolved in two of the three patients immediately after operation, which suggests a true association. It is interesting that these were the same two patients who had clinical findings suggestive of gastric outlet obstruction, which has frequently been found to be associated with altered bowel habit, following the original report by Dragstedt et al in 1947.?

Symptomatic patients require surgical exploration in order to obtain a definitive diagnosis and to exclude malignancy. Local excision is adequate if the lesion looks benign. This proved to be safe and effective in the treatment of the five patients reported here. Although any operation may be associated with a placebo effect, we feel that the relief of symptoms in our five patients resulted from the removal of a pathological lesion.

We conclude that pancreatic heterotopia may be responsible for gastrointestinal symptoms. Although uncommon, we feel that it is an important diagnosis to consider in patients found to have a benign looking tumour in the stomach or duodenum on gastroscopy or barium meal examination since it can be simply and effectively managed by local excision.

1 Film interpretation session. Radiological Society of North America, sixty-ninth scientific assembly and annual meeting November 1983. Summary of discussion and diagnoses. Radiology 1983; 149 (3): 861-74.

2 Martinez NS, Mortlock CG, Dockerty MB, et al. Heterotopic pancreatic tissue involving the stomach. Ann Surg 1958; 147 1-12.

3 Dolan RV, Remine WH, Dockerty MB. The fate of heterotopic pancreatic tissue. Arch Surg 1974; 109: 762-5.

4 Debray CH, Martin E. Benign gastric tumours. In: Bockus $\mathrm{H}$ ed. Gastroenterology Vol 1. Philadelphia: Saunders, 1974.

5 Lai EC, Tompkins RK. Heterotopic pancreas: review of a 26 year experience. Am $\mathscr{f}$ Surg 1986; 151 (6): 697-700.

6 Condon RE. Unusual disorders of the stomach and duodenum In: Nyhus LM, Wastell C, eds, Surgery of the stomach and In: Nyhus LM, Wastell C, eds, Surgery of the stomach and
duodenum. 3rd ed. Boston: Little, Brown and Co, 1977; 571-7. 7 Dragstedt LR, Harper PV, Tovee EB, Woodward ER. Section of Dragstedt LR, Harper PV, Tovee EB, Woodward ER. Section of
the vagus nerves to the stomach in the treatment of peptic ulcer - complications and end results after four years. Ann Surg 1947; 126: 687-708. 